Original Research Article

\title{
Prescribing pattern of fixed dose combinations of antibiotics in a post- operative surgical ward of tertiary care teaching hospital
}

\author{
Velvizhy R. ${ }^{1}$, Johan Pandian J. ${ }^{2 *}$
}

${ }^{1}$ Department of Pharmacology, Annaii Medical College \& Hospital, Pennalur, Sriperambadur, Kanchipuram 603402, India

${ }^{2}$ Department of Pharmacology, Mahatma Gandhi Medical College \& Research Institute, Pillaiyarkuppam, Puducherry 607402, India

Received: 22 September 2018 Accepted: 22 October 2018

\section{*Correspondence to: \\ Dr. Johan Pandian J., \\ Email: johanpandian@ gmail.com}

Copyright: (C) the author(s), publisher and licensee Medip Academy. This is an openaccess article distributed under the terms of the Creative Commons Attribution NonCommercial License, which permits unrestricted noncommercial use, distribution, and reproduction in any medium, provided the original work is properly cited.

\begin{abstract}
Background: Fixed dose drug combinations (FDCs), are combinations of two or more active drugs. It should be used when the combination has an established advantage over single drug in efficacy, safety and compliance. The World Health Organization (WHO) lists only 19 of such combinations. But Indian market is filled with hundreds of FDCs which were not approved leading to irrational use. This study was focused on finding out the fixed dose combination of antimicrobial agents used in the post-operative general surgery ward of a tertiary care teaching hospital.
\end{abstract}

Methods: After getting approval from institutional human ethics committee the prescriptions of patients admitted during April 2013 to March 2014 were analyzed. Demographic data, FDC prescribed by surgeons, Dose, Frequency, Duration, Route, Formulation, Brand or generic drugs, Adverse events due to use of FDC were collected and SPSS version 17 was used for statistical analysis. Fixed dose combinations were used in 90 Patients. The most commonly used FDC were ampicillin with Cloxacillin (43) followed by amoxicillin with clavulanic acid (22), cefoperazone with sulbactam (19) and piperacillin with tazobactam (6). A common drug used in combination along with FDC was metronidazole and aminoglycoside. The irrational combination seen in this study was ampicillin with Cloxacillin $(8.88 \%)$ of the total FDC which is not approved by DCGI or FDA.

Results: In this study out of 145 drugs used, 41drugs were administered three times a day, 90 drugs were given two times a day and 14 drugs were given once a day dosing. 53 patients received FDCs for prophylaxis and 37 patients for treatment purpose. All FDCs were prescribed in brand names. No adverse drug reaction was observed in this study.

Conclusions: Consultants should undergo continuing medical education (CME) on newer drug combinations and their adverse drug reactions which will be evidence-based rather than to rely on representatives.

Keywords: Drug utilization studies, Fixed dose combinations, Irrational combinations, WHO essential FDC list

\section{INTRODUCTION}

Fixed dose drug combinations (FDCs), are combinations of two or more active drugs in a single dosage form. They are suitable only when the dosage of each component meets the requisite and when the combination has an established advantage over single drug in efficacy, safety and compliance. ${ }^{1}$

WHO defines drug utilization as "The marketing, distribution, prescription and use of drug in a society with special emphasis on resulting medical, social and economic results". ${ }^{1}$ Surgical site infection (SSI) is the most 
common complication in post operative patients and represents a significant burden in terms of patient morbidity and mortality as well as cost to health services around the world. Among an estimated 27 million surgical procedures, surgical site infections are reported up to 500,000 cases each year. ${ }^{2}$ Surgical site infections are associated with increased antibiotic usage and costs, prolonged hospitalization, readmissions, permanent disability or even death of the patient. ${ }^{2}$

Although adequate antibiotic prophylaxis can reduce the risk of surgical site infections to some extent, but furthermore this favors the emergence of antimicrobial resistance. ${ }^{3}$ About $30-50 \%$ of antibiotic use in hospitals is for surgical prophylaxis; however $30-90 \%$ of this prophylaxis is not appropriate. ${ }^{4}$

There are many major challenges associated with correct SAP like type of procedure, the antibiotic prescribed, dosage and duration of the treatment which further complicates the problem. The discovery of antibiotics was a remarkable achievement of the twentieth century, before which patients who was in contact with common infectious diseases had significant morbidity and mortality. The discovery of penicillin in 1927 , followed by the discovery of other antibiotics decreased the mortality rate in a significant way from infectious disease..$^{5}$

Antimicrobials are the most common drugs, prescribed for several life threatening and trivial infections. Their importance is magnified in the developing countries, where infective diseases are predominant. ${ }^{6}$ It has been observed that $64 \%$ of antimicrobial agents prescribed are neither indicated nor appropriate in terms of drug selection and most of them are without an appropriate bacteriological basis which leads to the emergence of antibiotic resistant strains, treatment failure and increase in mortality and morbidity. ${ }^{7}$

So, this present study will be focused on finding out the current trends of prescribing fixed dose combination of antimicrobial agents in the post-operative ward of tertiary care teaching hospital.

\section{METHODS}

This was a prospective observational study, which was conducted at a tertiary care teaching hospital at Puducherry. It was approved by the institutional human ethics committee. Patients who were admitted in the postoperative ward of general surgery during April 2013 to March 2014 were taken.

\section{Inclusion criteria}

- All patients admitted in post-operative general surgery ward.

- Antimicrobials prescribed post-operatively were only considered.

\section{Exclusion criteria}

- $\quad$ Any patient who died post-operatively before being discharged

- $\quad$ Patient who absconded/discharged against medical advice.

Data were collected on a pretested case record form which included information on patient characteristics, surgical department under which admitted, type of operation, antimicrobial agents prescribed as well as their route of administration and timing of administration prior to surgery. Follow up data included additionally administered doses of antimicrobial agents, the total duration of prophylaxis as well as signs and symptoms of surgical site infections. If more than one drug was prescribed for a single procedure, all parameters for each drug were evaluated separately. The investigators did not intervene in patients' care in any way. ${ }^{8}$

\section{Statistical Analysis:}

The prescriptions of these patients were reviewed, and the details were collected at the time of their admission in post-operative ward. Demographic data, FDC prescribed by surgeons, Dose, Frequency, Duration, Route, Formulation, Brand or generic drugs, Adverse events due to use of FDC were entered into a Data Collection Proforma Sheet and were entered into Excel (MS Excel 2010). Descriptive statistics were applied to the data. The results were represented in the form of tables, pie charts and bar diagrams. SPSS version 17 was used for statistical analysis. ${ }^{9}$

\section{RESULTS}

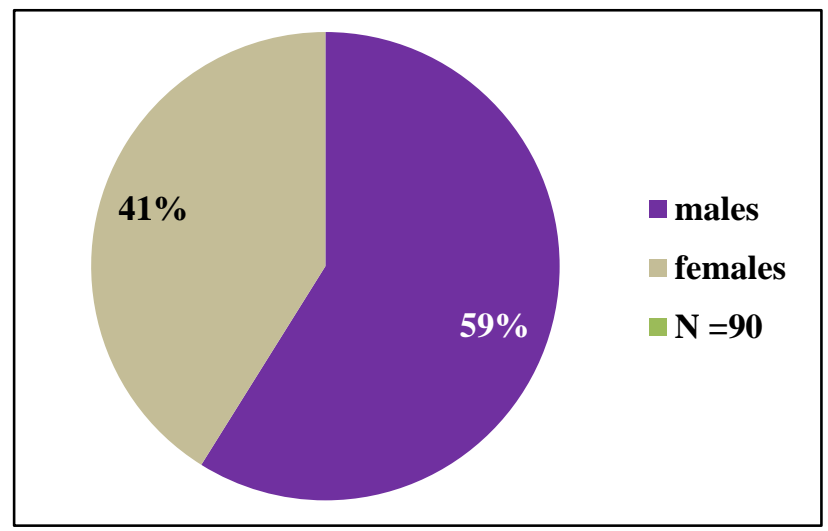

Figure 1: Male female ratio.

Age of the patients was ranging from 23 years to 74 years and the average age group of the patients was found to be 41.53. 46 patients received only FDC, 31 patients received FDC with one more drug and 13 patients received FDC with 2 drugs in addition. The most common being ampicillin with Cloxacillin followed by amoxicillin with clavulanic acid, cefoperazone with sulbactam and 
piperacillin with tazobactam. A common drug used along with FDC was metronidazole and aminoglycoside.

Table 1: Fixed dose combinations used.

\begin{tabular}{|lll|}
\hline & $\begin{array}{l}\text { Number of } \\
\text { patients } \\
\text { Drugs }\end{array}$ & Percentage \\
\hline $\begin{array}{l}\text { Inj. Ampicillin+Cloxacillin } \\
\text { Inj. }\end{array}$ & 24 & $26.8 \%$ \\
\hline $\begin{array}{l}\text { Cefoperazone+Sulbactam } \\
\text { Inj. }\end{array}$ & 4 & $4.4 \%$ \\
\hline $\begin{array}{l}\text { Piperacillin+Tazobactam } \\
\text { acid + } \\
\text { inj. Metronidazole }\end{array}$ & 2 & $2.2 \%$ \\
\hline $\begin{array}{l}\text { Inj.Cefoperazone+Sulbacta } \\
\text { m+inj.Metronidazole }\end{array}$ & 11 & $13.4 \%$ \\
\hline $\begin{array}{l}\text { Inj. } \\
\text { Ampicillin+Cloxacillin+ inj. } \\
\text { Metronidazole }\end{array}$ & 3 & $12.3 \%$ \\
\hline $\begin{array}{l}\text { Inj. } \\
\text { Ampicillin+Cloxacillin+ inj. } \\
\text { Gentamicin }\end{array}$ & 3 & $3.3 \%$ \\
\hline $\begin{array}{l}\text { Inj.Piperacillin+Tazobactam } \\
\text { +inj.Metronidazole }\end{array}$ & 2 & $3.3 \%$ \\
\hline $\begin{array}{l}\text { Inj. Amoxicillin+Clavulanic } \\
\text { acid+ } \\
\text { inj. Metronidazole + inj. } \\
\text { Amikacin }\end{array}$ & 4 & $2.3 \%$ \\
\hline $\begin{array}{l}\text { Inj. Amoxicillin+Clavulanic } \\
\text { acid + } \\
\text { inj. Metronidazole + inj. } \\
\text { Gentamicin }\end{array}$ & 3 & $4.4 \%$ \\
\hline $\begin{array}{l}\text { Inj.cefoperazone+ } \\
\text { sulbactam + } \\
\text { inj. Metronidazole + inj. } \\
\text { Amikacin }\end{array}$ & 4 & \\
\hline $\begin{array}{l}\text { Inj. } \\
\text { Piperacillin+Tazobactam + } \\
\text { inj. Metronidazole + inj. } \\
\text { Ciprofloxacin }\end{array}$ & 2 & \\
\hline C. Ampicillin+Cloxacillin & 13 & \\
\hline $\begin{array}{l}\text { T. Amoxicillin+Clavulanic } \\
\text { acid }\end{array}$ & 3 & \\
\hline
\end{tabular}

In this study out of 145 drugs used, 41drugs were administered three times a day, 90 drugs were given two times a day and 14 drugs were given once a day dosing. 53 patients received FDCs for prophylaxis and 37 patients for treatment purpose. All FDCs were prescribed in brand names. No adverse drug reaction was observed in this study.

Maximum number of subjects among males was from the age group more than $60 \mathrm{y}(23.07 \%)$ followed by $18-30 \mathrm{y}$ $(19.23 \%)$ and $41-50$ y $(19.23 \%)$. Maximum number of subjects among the females was from the 18-30 (45.90\%) age group. Prescriptions were studied among females were higher $(53.98 \%)$ than among males $(46.02 \%) .11 \%$ of total prescription were studied from paediatric age group.

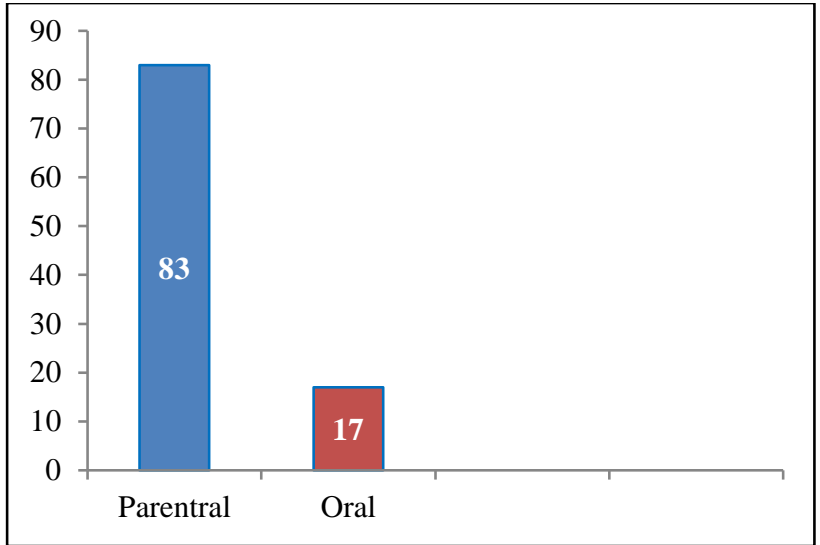

Figure 2: Percentage of drugs given oral vs parenteral.

Median duration of stay among three departments i.e. ENT, surgery and OandG was $4 \mathrm{~d}$. Maximum median duration of stay was nine days in Orthopaedics. Highest number of subjects stayed for nine days in the orthopaedic department.

\section{DISCUSSION}

Fixed dose combinations were used in 90 (18.59\%) patients, of whom 46 patients received only FDC, 31 patients received FDC with one more antimicrobial agent and 13 patients received FDC with 2 antimicrobial agents in combination. The most commonly used FDC were ampicillin with Cloxacillin followed by amoxicillin with clavulanic acid, cefoperazone with sulbactam and piperacillin with tazobactam. A common drug used in combination along with FDC was metronidazole and aminoglycoside. The use of FDC was lower in this study when compared to Amane et al, in which $31.85 \%$ of prescription contained FDC and the most common was quinolones with nitroimidazoles. ${ }^{10}$

Antimicrobial agents are important category of drugs which are essential in treating or preventing development of infections in patients. Post operative Patients in surgical wards develop infections which are caused by bacteria that are highly virulent. ${ }^{11}$ The use of antibiotics in such patients for treatment of infections is a justifiable practice. However, it requires review of the chosen regimen on regular basis for monitoring efficacy, toxicity, cost and other aspects to maximize the benefits to the patient. With the advent of antibiotics and their widespread use, the incidence of wound infection has come down remarkably. The present study is an attempt to monitor the current scenario about the antibiotics, that how they are being used amongst post operative patients. ${ }^{12}$

The irrational combination seen in this study was ampicillin with Cloxacillin (8.88\%) which is neither approved by DCGI or FDA nor were included in the NLEM or WHO EML. ${ }^{13}$ The reason for this irrational FDC is due to lack of information. Most of our practitioners rely on medical representatives who induce the doctors with 
false information, defective drug supply system and ineffective drug regulation, i.e. absence of well-organized drug regulatory authority and presence of large numbers of drugs in the market leads to irrational use of drugs. ${ }^{14,15}$

\section{CONCLUSION}

The prescribers should undergo a continuing medical education (CME) course, once in a year to be aware of the newer drug combinations introduced into the market and their adverse drug reactions, so that the prescribing practices become not only justifiable but evidence-based also. The short comings of our study are that the analysis has been confined to a limited ward. In future prescriptions from all the wards and OPD's should be analyzed for irrational FDC's. It should not only end here but to be continued on a regular basis so that we can minimize and ensure better prescriptions which in turn will directly impact on treatment outcomes.

\section{ACKNOWLEDGEMENTS}

Authors would like to thank the consultants of general surgery as they were generous enough to accept this criticism and provide them with valuable information and constant support.

Funding: No funding sources Conflict of interest: None declared

Ethical approval: The study was approved by the Institutional Ethics Committee

\section{REFERENCES}

1. Gautam CS, Saha L. Fixed dose drug combinations (FDCs): rational or irrational: a view point. Br J Clin Pharmacol. 2008;65(5):795-6.

2. The selection and use of essential medicines-WHO technical report series: No.914; 2003:132. (Internet); cited 2014 Aug 18. Available at: http://apps.who.int/medicinedocs/en/d/Js4875e/5.2.ht $\mathrm{ml}$

3. Sreedhar D, Janodia MD, Ligade VS, Mohapatra S, Ganguly R, Udupa N Fixed dose combinations: Rational or irrational? Current science. 2008;95(5)10:581-2.

4. Tripathi KD. Antimicrobial drugs, Essentials of Medical Pharmacology. $7^{\text {th }}$ Ed, 12. New Delhi, JAYPEE Brothers medical publishers; 2013:688-704.

5. Chambers HF, Sande MA. Antimicrobials: General considerations. In Hardman, JG and Limbird LE, (Eds) Goodman and Gilman's. The pharmacological basis of therapeutics $8^{\text {th }}$ ed. MC Graw Hill; 1996:10501053.

6. Woldu MA, Suleman S, Workneh N, Berhane H. Retrospective study of the pattern of antibiotic use in Hawassa University Referral Hospital Pediatric Ward, Southern Ethiopia; J App Pharm Sci. 2013;3(02):93-8.

7. Amane H, Priyadarshini K. Prescription analysis to evaluate rational use of Antimicrobials. International Journal of Pharma and Bio Sciences. 2011;2(2):314-9.

8. National List of Essential Medicines of India 2011 (internet); cited 2014 Aug 18. Available at: 2011http://www.cdsco.nic.in/writereaddata/National $\% 20$ List $\% 20$ of\%20Essential\%20Medicine$\% 20$ final\%20copy.pdf

9. Brahma D, Marak M, Wahlang J. Rational Use of Drugs and Irrational Drug Combinations. The Internet J Pharmacology. 2012;10(1). (cited 2014 Aug 23). Available at: ISPUB.com/IJPHARM/10/1/14081

10. Culver DH, Horan TC, Gaynes RP, Martone WJ, Jarvis WR, Emori TG, et al. Surgical wound infection rates by wound class, operative procedure, and patient risk index. National Nosocomial Infections Surveillance System. Am J Med. 1991;91(3B):152S$7 \mathrm{~S}$.

11. Haley RW. Nosocomial infections in surgical patients: Developing valid measures of intrinsic patient risk. American J Med. 1991;91(3):145-51.

12. Mangram AJ, Horan TC, Pearson ML, Silver LC, Jarvis WR. Guideline for Prevention of Surgical Site Infection, 1999. Centers for Disease Control and Prevention (CDC) Hospital Infection Control Practices Advisory Committee. Am J Infect Control. 1999;27(2):97-132. quiz 133-4; discussion 96.

13. ASHP therapeutic guidelines. Clinical practice guidelines for antimicrobial prophylaxis in surgery. Am J Health-Syst Pharm. 2013;70:624-709.

14. National Centre For Disease Control. National treatment guidelines for antimicrobial use in infectious diseases. Directorate General of Health Services, Ministry of Health and Family Welfare, Govt. of India; 2016:41.

15. Rehan HS. Surgical antibiotic prophylaxis in a tertiary care teaching hospital in India. Inter J Infec Control. 2010;6(2):1-6.

Cite this article as: Velvizhy R, Pandian JJ. Prescribing pattern of fixed dose combinations of antibiotics in a post-operative surgical ward of tertiary care teaching hospital. Int J Basic Clin Pharmacol 2018;7:2332-5. 